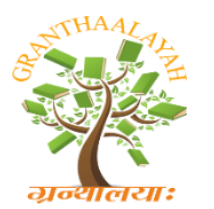

$$
\begin{gathered}
\text { INTERNATIONAL JOURNAL OF RESEARCH } \\
\text { GRANTHAALAYAH } \\
\text { A knowledge Repository }
\end{gathered}
$$

Management

\title{
THE EFFECT OF TRAINING AND DEVELOPMENT ON JOB SATISFACTION, SKILL ENHANCEMENT AND MOTIVATION OF EMPLOYEES
}

\author{
Dr. M. N. Zubairi ${ }^{1}$, Tahsin Zaman Khan ${ }^{2}$ \\ ${ }^{1}$ Associate Professor, University Department of Commerce \& Business Management \\ Ranchi University, Ranchi, Jharkhand, India \\ ${ }^{2}$ Research Scholar, University Department of Commerce \& Business Management \\ Ranchi University, Ranchi, Jharkhand, India
}

\begin{abstract}
This study examines the effect of training and development on job satisfaction, skill enhancement and motivation of employees in Mahindra Group, India. A total number of 150 participants from Mahindra Group, India were involved in the study. The study made use of questionnaires as research instrument. The results of the study show a significant difference in T\&D among gender of workers in a way that female employees had a higher mean score on T\&D compared to male colleages. Also, here was a strong positive significant correlation between skill enhancement and motivation which implies that effective skill enhancement program will give rise to high level of motivation among workers. Additionally, there was a strong positive significant relationship between $T \& D$ and Job satisfaction, between $T \& D$ and motivation and a significant relationship between T\&D and skill enhancement. This study recommends that that companies and organizations training and development would effectively motivate workers, influence job satisfaction and improve skill enhancement among workers.
\end{abstract}

Keywords: Training \& Development; T\&D; Job Satisfaction; Skill Enhancement; Motivation; Employees.

Cite This Article: Dr. M. N. Zubairi, and Tahsin Zaman Khan. (2018). "THE EFFECT OF TRAINING AND DEVELOPMENT ON JOB SATISFACTION, SKILL ENHANCEMENT AND MOTIVATION OF EMPLOYEES." International Journal of Research - Granthaalayah, 6(11), 290-298. https://doi.org/10.29121/granthaalayah.v6.i11.2018.1130.

\section{Introduction}

Many organizations have discovered that human capital development in terms of training and development is highly profitable. Those that identify their employees' worth and put in place proper training plans turn out to be competitive, thriving and lucrative. Based on a research carried out in 2002 by Knowledge Assessment Management, firms within the $20 \%$ of those that invest in training are among the most lucrative in the stock market. 
Some training programs train new workers to carry out a specific task and some others improve the knowledge and skills of existing workers. Training in innovation technology is required by employees in diverse as production, transportation, health and construction. Innovation technology has revolutionized so many industries; as a result, there is consistent alteration in job functions, which shows that a lot of employees need to skill upgrade consistently.

Global economy has been differentiated by severe competition and fast advancement in innovative technology since 1990. As a result of speedy changes taking place in global economy and consistent reformation in companies, organizational structure and work practices are changing rapidly. As a result of the changes, the demand for innovative skills in existing jobs is on the increase, high altitude of skilled workforce to fit into the dynamic structures of organizations and work profiles. The dynamic structure of changes has an important effect on Training and Development (T\&D) of employees. Organizations should ensure a consistent plan to improve the dimension and competitiveness of the skill of their workers is in place. In this aspect, T\&D has a vital role to play. As a result of the nature of competition, innovative technology and dynamic organizational formation, skills of workers need to be improved and there is need for consistent skill up graduation in order to avoid obsolescence. Organizations encounter various problems in business as a result of innovation, competitions, changing in production activities and employee turnover as a result of dynamic nature of the workplace environment. In a bid to handle the changes, it is essential for managers to make accurate decisions and ensure they have in place quality and dynamic human resources by engaging individuals with adequate proficiencies and skills.

In India presently, only a small number of organizations emphasize on T\&D. Training is an intended and organized effort to change or expand skill, understanding, and approach via learning practice in order to gain effectual performance in variety of activities. Training process is an occasion to acquire knowledge and is based on various factors which include planning and implementation, the motivation and style of teaching of the trainers and the type of environment the training is being conducted. The significance of formal training should be envisaged in the framework of the training model which is in place in Indian companies. The impact of knowledge on employees is on the increase. The changing rate is rapid and skills are being improved. The requirement of training is centered on three reasons. The number reason is liberalization that has removed obstacles and allowed easy entry for local and international companies. The number two reason is on demand and supply of talented expertise that has made retention of workers a major issue for CEOs. The number three reason is high anticipation of workers concerning their proficiency and personal advancement. Most Indian organizations have been allotting funds for training as an act of fate for proficiency and tactical way of thinking. Various methods of training are utilized by faculties and trainers in various organizations. The content of the training plan needs to contain quality method with objectives of the training. Some reputable organizations in corporate India have utilized modern methods of training and have recorded exceptional advancement based on training schemes leading to high level of competition especially in the moderate entry of MNC. The promising business scenario calls for evaluation of the present training and skill development system.

A lot of today's outstanding organizations recognize that their workers are their most valuable asset. As a result, organizations are progressively investing in training their workers so as to 
develop and bring about innovation in the organization for more profitability. The various training schemes differs considerable from organization to organization, as a result, when looking for prospective employers, job seekers who show concern about this should examine the kind and schemes of training that are given to workers. After workers have been employed and allocated to different positions in a company, making them to undergo training for particular tasks which have been assigned to them presumes greater importance.

T\&D depicts the official, ongoing attempts made in organizations to advance the performance and personal accomplishment of their workers via various methods of training and programs. In the contemporary workplace, these endeavors are carried out on various types of equipments ranging from tutoring in exceedingly specific skills to durable professional advancement. Recently, T\&D has surfaced as an official business role, an essential component of strategy, and an acceptable profession with diverse theories and strategies. Many organizations of different sizes have adopted "continual learning" including various aspects of T\&D as a way of advancing workers growth and securing a proficiently skilled work force.

Taylor (1961) stressed that training is a way of bringing about an incessant improvement in the performance of work quality; it will furnish them with adequate knowledge, capability, skills and approach to work performance. According to Singh (1995), training is the practice of changing approaches, advancing knowledge and improving skills of the workers of a company in order to motivate them for effective job performance. DeCenzo \& Robbins (2000), explain training as a "learning experience, in that, it seeks a relatively permanent change in an individual that will improve his ability to perform on the job". This shows that training must be planned in a manner that it will include enhancement of skills, acquisition of knowledge and social conduct. The skill enhancement, acquisition of knowledge and social conduct may include what the worker knows, his way of working, his relationship and the way he interacts with his colleagues and superiors at work. Monappa \& Saiyadain (2008), define training as "the tutoring or learning processes carried out for the major aim of assisting workers of a company to obtain and utilize the skills, knowledge and behavior required by that organization. Training has implication on productivity, health and safety at work and personal development. All organizations employing people need to train and develop their staff. Most organizations are cognizant of this requirement and invest effort and other resources in training and development. Such investment can take the form of employing specialist training and development staff and paying salaries to staff undergoing training and development. Investment in training and development entails obtaining and maintaining space and equipment. It also means that operational personnel, employed in the organization's main business functions, such as production, maintenance, sales, marketing and management support, must also direct their attention and effort from time to time towards supporting training development and delivery.

Organizations in both the private and public sectors, regardless of types or nature of organization, agree that training and development is essential to the growth and development of the business (Noe, 2002). Many organisations adopt a more strategic \& future oriented approach to training and development to build employee capability within the business.

Although the terms training and development are used together, they are often confused. Training means learning the basic skills and knowledge necessary for a particular job or a group of jobs. In other words, training is the act of increasing the knowledge for doing a particular job. But 
development refers to the growth of an individual in all respects. An organization works for the development of its executives or potential executives in order to enable them to be more effective in performing the various functions of management.

Indian Industry is presently on a fast development track. Improved technology and techniques are being imported from developed countries. In the context of globalization, human resource development with proper training to the workforce is required to meet the challenges in future and to win the global competitive advantage.

Organizations in India can be more competitive than their counterparts via innovative technology and proper knowledge of the needs of their customers. The quality of service component, and instrument to generate customer value, is naturally determined by the people delivering it. Companies in India have brought more innovation not only into their recruitment style but also the type of workers they hire and market talent hunt. They make use of T\&D to fill the gap of skills. Job satisfaction is a demonstration and expression of a worker in relation to a specific aspect of their job such as remuneration, compensation and authority that may be related to a specific result. Motivation is a combination of features which enables employees to work joyfully and adequately. Motivation triggers and controls behaviour. Motivated employees will possibly work joyfully and harder. Motivation is associated with performance. Great level of job motivation will possibly result into a higher level of job performance, and this is the expectation of employers. According to Wegner and Miller (2003), motivation is what invigorate individuals to act and is related to the choices a person accepts along with his aim, objectives and behaviour. Fuller et.al. (2008) opined that motivation is an individual's passion, path and consistency of attempts to achieve a particular goal.

Effective use of motivation-enhancing practices such as incentives and other rewards-forperformance practices satisfy competence and relatedness needs, thus resulting in increased affective commitment. Such practices signal a positive valuation of employees and their efforts by the company (Appelbaum et al., 2000). Appelbaum et al.'s (2000) work showed a positive relationship between motivation-enhancing practices and individual commitment.

\section{The Statement of Problem}

This study will examine the effect of T\&D on job Satisfaction, skill enhancement and motivation of employees in an organizational setup using Mahindra Group as a case study. The study objectives are enumerated below:

1) To find out the impact of training and development on male and female employees.

2) To find out relationship between skill enhancement and motivation of workers

3) To find out the impact of Training and development on job satisfaction, skill enhancement and motivation of the employees in an organization.

\section{Hypotheses}

Hypothesis 1: Training and development is more effective among male employees than female employees

Hypothesis 2: Skill enhancement does not have significant effect of motivation of workers. 
Hypothesis 3: Training and development does not have a significant impact on job satisfaction, skill enhancement and motivation of the employees in an organization.

Saraswathi (2011) explained motivation as the readiness to apply great level of exertion to organizational objectives, stipulated by the effort's capacity to ensure that some people's needs are satisfied. Baba Gana and Bababe (2011) stressed that inadequate motivation could result into poor performance within the workforce. According to Nankervis, Compton and McCarthy (1999), effective training would not only furnish employee with adequate knowledge and skills required to complete jobs, it would also assist to achieve overall organization goals by contributing to the satisfaction and productivity of employee.

The study of Singh and Tiwari (2011) showed that there was a strong positive relationship between Motivation and Job Satisfaction of the workers. Also, the study of Nadia and Shagufta (2011) show the same result. With a sample of 80 middle administrators from various banks in Pakistan, they reported that there was a positive relationship between work motivation and Job Satisfaction.

\section{Research Methodology}

This research work is based on primary data. A questionnaire was used to obtain the information on the impact of training and development on job satisfaction, motivation and skill enhancement in Mahindra, India. A total number of 150 participants from Mahindra Group, India were involved in the study. The study made use of questionnaires as research instrument. In order to increase their level of confidence and trust, the anonymity and confidentiality aspect was also highlighted. The responses of the questionnaire were analyzed using SPSS Version 21.0 and statistical tests like Independent Sample T-test and Pearson Correlation were used in analyzing the hypotheses.

\section{Result and Discussion}

This section is centered on the result of data analysis and discussion.

\section{Data Analysis}

Table 1: Demographic Characteristics of Respondents

\begin{tabular}{|c|c|c|}
\hline General Profile & Frequency & Percentage \\
\hline \multicolumn{3}{|l|}{ Gender } \\
\hline Male & 62 & 41.3 \\
\hline Female & 88 & 58.7 \\
\hline \multicolumn{3}{|l|}{ Age (Years) } \\
\hline Less than 30 & 72 & 48.0 \\
\hline $31-50$ & 62 & 41.3 \\
\hline 50 and Above & 16 & 10.7 \\
\hline \multicolumn{3}{|c|}{ Educational Qualification } \\
\hline Secondary & 3 & 2.0 \\
\hline Graduates & 77 & 51.3 \\
\hline Postgraduates & 28 & 18.7 \\
\hline Professionals & 42 & 28.0 \\
\hline
\end{tabular}




\begin{tabular}{|l|l|l|}
\hline Experience (Years) & & \\
\hline $1-5$ & 53 & 35.3 \\
\hline $6-10$ & 75 & 50.0 \\
\hline $11-15$ & 11 & 7.3 \\
\hline $16-20$ & 11 & 7.3 \\
\hline Department & & \\
\hline Marketing & 52 & 34.7 \\
\hline IT & 27 & 18.0 \\
\hline Finance & 31 & 20.7 \\
\hline HRM & 15 & 10.0 \\
\hline R\&D & 11 & 7.3 \\
\hline Admin & 14 & 9.3 \\
\hline Total & $\mathbf{1 5 0}$ & $\mathbf{1 0 0 . 0}$ \\
\hline
\end{tabular}

Table 1 shows that $62(41.3 \%)$ of the respondents were male while $88(58.7 \%)$ were female and $72(48.0 \%)$ were less than 30 years, $62(42.3 \%)$ were within the age of 31-50 years while 16 $(10.7 \%)$ were 50 years and above.

In addition, $77(51.3 \%)$ were Graduates, 42 (28.0\%) were professionals, 28 (18.7\%) had postgraduate qualifications while $3(2.0 \%)$ had Secondary school certificates. On the level of experience of respondents, $75(5.0 \%)$ had 6-10 years experience, $53(35.3 \%)$ had 1-5 years experience, while 11 (7.3\%) had 11-15 years and 16-20 years experience respectively. Furthermore, many of the respondents were in Marketing department which accounts for 52 (34.7\%), 31 (20.7\%) were in Finance department, 27 (18.0\%) were in IT departments, 15 (10.0\%) were in HRM departments while 14 (9.3\%) were in Admin department.

Hypothesis One: Training and development is more effective among male employees than female employees

\section{Gender and Training and Development}

Table 2: Independent Sample T-test showing significant difference in training and development among male and female employees

\begin{tabular}{|l|l|l|l|l|l|l|l|}
\hline DV & Gender & N & Mean & SD & Df & T & \\
\hline \multirow{2}{*}{ Training and Development } & Female & 62 & 1.65 & 1.44 & & & \\
\cline { 2 - 9 } & Male & 88 & 1.09 & .517 & 148 & 3.326 & $<.05$ \\
\hline
\end{tabular}

Results from table 2 shows that there is a significant different in training and development among gender of workers $(\mathrm{t}(148)=3.326, \mathrm{p}<.05)$, such that female workers score higher on training and development $($ Mean $=1.65, \mathrm{~S} . \mathrm{D}=1.44)$ compared to male workers $($ Mean $=1.09, \mathrm{~S} . \mathrm{D}=.517)$ which implies that the impact of training and development is higher among female workers than male workers.

Hypothesis 2: Skill enhancement does not have significant effect of motivation of workers. 


\section{Skill enhancement \& Motivation}

Table 3: Correlation between Skill enhancement and motivation

\begin{tabular}{|l|l|l|l|l|}
\hline Variable & Skill enhancement & Motivation & Mean & SD \\
\hline Skill enhancement & 1 & $.963 * *$ & 7.19 & 2.93 \\
\hline Motivation & $.963 * *$ & 1 & 1.72 & 0.95 \\
\hline
\end{tabular}

** Correlation is significant at 0.01 level (2-tailed)

Results from table 3 reveal that there is a strong positive significant correlation between skill enhancement and motivation $(\mathrm{r}=.963, \mathrm{p}<.05)$. This implies that effective skill enhancement program will give rise to high level of motivation among workers while ineffective skill enhancement among workers could lead to low level of motivation.

Hypothesis 3: Training and development does not have a significant impact on job satisfaction, skill enhancement and motivation of the employees in an organization

Table 4: Correlation between Training \& Development, job satisfaction, skill enhancement and motivation of workers

\begin{tabular}{|l|l|l|l|l|l|l|}
\hline Variable & $\begin{array}{l}\text { Training \& } \\
\text { Development }\end{array}$ & $\begin{array}{l}\text { Job } \\
\text { satisfaction }\end{array}$ & $\begin{array}{l}\text { Skill } \\
\text { enhancement }\end{array}$ & Motivation & Mean & SD \\
\hline $\begin{array}{l}\text { Training \& } \\
\text { Development }\end{array}$ & 1 & $.943^{* *}$ & $.480^{* *}$ & $.821^{* *}$ & 1.32 & 1.04 \\
\hline Job satisfaction & $.943^{* *}$ & 1 & $.539 * *$ & $.908^{* *}$ & 5.12 & 4.02 \\
\hline $\begin{array}{l}\text { Skill } \\
\text { enhancement }\end{array}$ & $.480^{* *}$ & $.539^{* *}$ & 1 & $.437^{* *}$ & 6.35 & 1.93 \\
\hline Motivation & $.821^{* *}$ & $.908^{* *}$ & $.437 * *$ & 1 & 1.35 & 1.13 \\
\hline
\end{tabular}

** Correlation is significant at 0.01 level (2-tailed)

Table 4 shows that there is a strong positive significant correlation between training \& development and Job satisfaction $(\mathrm{r}=.943, \mathrm{p}<.05)$, a strong positive correlation between training and development and motivation $(\mathrm{r}=.821, \mathrm{p}<.05)$ and a correlation between training and development and skill enhancement $(\mathrm{r}=.480, \mathrm{p}<.05)$. This implies that high level of training and development will enhance job satisfaction, motivate workers and improve skill enhancement at their place of work.

Definition of Abbreviations used in Analysis, definitions of variables, factors, co-effieceint Dependent variable (DV): Training \& Development

Independent Variables (IV): Motivation, Skill enhancement, Job Satisfaction

Df $=$ Degree of Freedom

$\mathbf{S D}=$ Standard deviation

$\mathbf{P}=$ Probability value

\section{Conclusion and Recommendation}

The result of the study shows that $T \& D$ has a significant effect on job satisfaction and motivation of workers. The result of hypothesis one reveals a significant difference in T\&D among gender of 
workers in a way that female employees score higher on T\&D compared to male employees which implies that T\&D was quite effective among female compared to male employees. This finding agrees with Stephce (2009) that reported gender difference in connection to problem solving and that a girl work on the application issues with little subjective motivational proficiency compared to a boy and more disposed than boys to relate bad results to inefficient capacity, low motivation complexity of tasks.

The result of the second hypothesis shows that there was a strong positive significant correlation between skill enhancement and motivation which implies that effective skill enhancement program will give rise to high level of motivation among workers while ineffective skill.

The result of hypothesis three shows a strong positive significant relationship between T\&D and Job satisfaction and a strong positive relationship between $T \& D$ and motivation and a relationship between T\&D and skill enhancement which infers that high level of T\&D will enhance job satisfaction, motivate workers and improve skill enhancement at their place of work. This finding supports Nankervis, Compton and McCarthy (1999) who are of the opinion that effective training would not only equip employee with most of the knowledge and skills needed to accomplish jobs, it would also help to achieve overall organization objectives by contributing to the satisfaction and productivity of employee. The result is also in line with Sahinidis and Bouris (2008) who examined workers' perceived training efficiency and its connection with employee attitudes in five large companies in Greece. They used 134 employees for the study and the multiple regression and Spearman correlation tests revealed that training influenced employees' commitment, job satisfaction and motivation in different industries. They also found that commitment, job satisfaction and motivation were highly correlated.

The recommendation of this study based on the findings is that companies and organizations training and development would effectively motivate workers and influence job satisfaction among workers.

\section{References}

[1] Appelbaum, E., Bailey, T., Berg, P. and Kalleberg, A. 2000. Manufacturing advantage: why highperformance work systems pay off. Ithaca: Cornell University Press.

[2] Baba Gana, A. \& Bababe, F.B. (2011). The effect of motivation workers performance. A case of Maiduguri Flour Mill Ltd, Borno State, Nigeria. Continental Journal of Social Sciences, 4(2), 8-13

[3] DeCenzo, A. D, \& Robbins, P. S. (2000). Personnel / Human Resource Management 4th ed. Prentice-Hall, New Delhi, India

[4] Fuller, M.A., Valacich, J.S., \& George, J.F. (2008). Information Systems Project Management: A Process and Team Approach. Upper Saddle River, New Jersey: Pearson Prentice Hall

[5] Monappa, A \& Saiyadain, M. (2008). Personnel Management 2nd ed. Tata McGraw-Hill, New Delhi.

[6] Murphy, B. (2004) Nursing Home Administrators? Level of Job satisfaction, Journal of Healthcare Management; Sep/Oct; 49, 5; p. 344.

[7] Nadia, A. \& Shagufta, R. (2011). The Relationship Between Work Motivation and Job Satisfaction. Pakistan Business Review, July 2011.

[8] Nankervis, A. R., Compton, R. L., and McCarthy, T. E. (1999). Strategic Human Resource Management, (3rd Ed.), Nelson ITP, Melbourne.

Noe, R. A. (2002), Employee Training and Development" McGraw Hill. 
[9] Sahinidis, A.G. \& Bouris,J. (2008) "Employee perceived training effectiveness relationship to employee attitudes", Journal of European Industrial Training, Vol. 32 Issue: 1, pp.63-76, https://doi.org/10.1108/03090590810846575

[10] Saraswathi, S. (2011): A Study on Factors that Motivate IT and Non-IT Sector Employees: A Comparison. International Journal of Research in Computer Application and Management, Vol. 1 (2), pp. 72-77.

[11] Singh, K. (2004) "Impact of HR practices on perceived firm performance in India", Asia Pacific Journal of Human Resources, 2004, 301-317

[12] Singh, S.K. \& Tiwari, V. (2011). Relationship between Motivation and Job Satisfaction of the White Collar Employees: A Case Study. Management Insight, Vol 7, No 2 (2011)

[13] Stephce. (2009). Motivation and gender. Online: http://www.studymode.com/essays/MotivationAnd-Gender-213917.html. Accessed April 122014.

[14] Taylor, P. (1961). A new integrated framework for training needs analysis. Human Resource Management Journal, 8(2), 29-50. doi: 10.1111/j.1748-8583. 1998.tb00165.x

[15] Wegner, F. W. \& Miller, L. S. (2003). Effective Police Supervision, Cincinnati, Anderson Publishing Co.

\footnotetext{
*Corresponding author.

E-mail address: sarfaraz7216@ gmail.com
} 